\title{
Pengaruh Knowledge Sharing Terhadap Kinerja Karyawan Pada PT PLN (Persero)
}

\author{
Khaerana ${ }^{\mathrm{a}}$ \\ Berlin Mangiwa \\ aUniversitas Andi Djemma Palopo, khaerana.itowotu@gmail.com \\ bUniversitas Andi Djemma Palopo, berlinmangiwa01@gmail.com
}

\begin{abstract}
A b s t r a k
Penelitian ini dilakukan pada PT. PLN (PERSERO) Kota Palopo, bertujuan untuk mengetahui pengaruh knowledge sharing terhadap kinerja karyawan pada PT. PLN (PERSERO) Cabang Kota Palopo. Populasi pada penelitian ini sebanyak 45 responden yang merupakan karyawan pada PT. PLN (PERSERO) Cabang Kota Palopo, sementara penentuan jumlah sampel dengan menggunakan teknik sampling total (sensus), sehingga jumlah sampel sama dengan jumlah populasi. Data penelitian ini diperoleh dari observasi, kuesioner dan wawancara secara langsung. Hasil penelitian menunjukkan bahwa nilai $t_{\text {hitung }}>t_{\text {tabel }}$ yaitu $5.378>2.016$ dan nilai signifikansi $0.000<0.05$, serta nilai koefisien regresi variable knowledge sharing bernilai positif sebesar 0.483, sehingga dapat dimaknai bahwa variable knowledge sharing berpengaruh positif dan signifikan terhadap kinerja karyawan pada PT. PLN (Persero) Cabang Kota Palopo. Sedangkan koefisien determinasi $\left(R^{2}\right)$ menunjukkan nilai $R$ Square sebesar 0.402 atau $40.2 \%$, sehingga dapat diinterpretasikan bahwa knowledge sharing mampu mempengaruhi kinerja karyawan sebesar 40,2\% dan sisanya sebesar 59.8\% dipengaruhi oleh variabel lain yang tidak diteliti dalam penelitian ini.
\end{abstract}

Kata Kunci: Knowledge Sharing, Kinerja Karyawan, Sumber Daya Manusia, Organisasi.

\section{A b s t r a c t}

This research was conducted at PT. PLN (PERSERO) Palopo City aims to determine the effect of knowledge sharing on employee performance at PT. PLN (PERSERO) Palopo City Branch. The population in this study was 45 respondents who were employees at PT. PLN (Persero) Palopo City Branch, while determining the number of samples using the total sampling technique (census), the number of samples is the same as the total population. The data of this study were obtained from observations, questionnaires, and direct interviews. The results showed that the value of $t$ _count $>t$ table was $5.378>2.016$ and a significance value of $0.000<0.05$, and the regression coefficient value of the knowledge sharing variable was positive at 0.483 , so it can be interpreted that the knowledge sharing variable has a positive and significant effect on employee performance at PT. PLN (PERSERO) Palopo City Branch. While the coefficient of determination $(R 2)$ shows an $R$ Square value of 0.402 or $40.2 \%$, so it can be interpreted that knowledge sharing can affect employee performance by $40.2 \%$, and the remaining $59.8 \%$ is influenced by other variables not examined in this research.

Keywords: Knowledge Sharing, Employee Performance, Human Resources, Organization.

\section{Pendahuluan}

Saat ini kita telah berada pada era industri 4.0, dimana perkembangan ilmu pengetahuan dan teknologi membawa pengaruh yang sangat besar dan begitu cepat sehingga berdampak ke berbagai aspek kehidupan, baik dalam lingkungan masyarakat maupun lingkungan organisasi/perusahaan, khususnya terhadap kinerja sumber daya manusia. Untuk itu, sumber daya manusia yang ada dalam suatu perusahaan diharapkan 
berkompeten dan menghasilkan kinerja yang maksimal. Untuk mendapatkan hal tersebut, perusahaan menggunakan berbagai cara, mulai dari memberikan pelatihan, seminar, mewajibkan menjadi anggota suatu organisasi profesi tertentu dan sebagainya.

Kinerja merupakan hasil yang dicapai oleh individu dari pekerjaan yang telah dilakukan sesuai dengan ketentuan yang berlaku dalam organisasi/ perusahaan. Pencapaian tujuan organisasi/perusahaan menunjukkan hasil kerja atau prestasi kerja organisasi. Hasil kerja organisasi diperoleh dari serangkaian aktivitas yang dijalankan oleh setiap individu (karyawan) yang ada di dalam organisasi. Apabila karyawan jelas memahami tentang apa yang diharapkan dari mereka dan mendapat dukungan yang diperlukan untuk memberikan kontribusi pada organisasi secara efisien dan produktif. Oleh karena itu kinerja dari karyawan dapat mempengaruhi kinerja organisasi/perusahaan itu juga.

Knowledge management (manajemen pengetahuan) berperan penting dalam organisasi, karena dapat menununjukkan inisiatif dan dan prosedur pengelolaan yang jelas, mudah dimengerti, dan komprehensif. Apabila organisasi gagal dalam memanfaatkan aset yang tidak dapat dihitung (tangible), yaitu knowledge, maka konsekwensinya adalah kegagalan untuk selalu ada (exist). Oleh karena itu knowledge sharing (berbagi pengetahuan) perlu dilakukan yang didasarkan pada kepercayaan (Nawawi, 2012). Manajemen pengetahuan terkait dengan berbagi pengetahuan (knowledge sharing). Knowledge sharing merupakan bagian penting bagi peningkatan sumber daya manusia dalam organisasi. Peningkatan sumber daya manusia tersebut akan dapat memberikan daya ungkit bagi setiap proses efektif dalam organisasi (Tung, 2018).

Badan Usaha Milik Negara (BUMN) harus dapat memberikan kepuasan dan citra yang baik di mata konsumen dengan cara memberikan kinerja yang berkualitas. Melihat keadaan tersebut, pemerintah berupaya agar BUMN berusaha untuk berinovasi dalam hal ini memberikan kinerja yang terbaik bagi masyarakat sebagai konsumen. Salah satu wujud dari kinerja itu sendiri adalah dengan memberikan pelayanan yang baik kepada masyarakat, sehingga masyarakat akan merasa dihargai dan haknya tidak terabaikan. Permasalahan manajemen dalam perusahaan yang sering terjadi justru karena kurangnya informasi yang diperlukan karyawan untuk melaksanakan tugasnya. Keberhasilan knowledge sharing tergantung dari kualitas dan kuantitas komunikasi antar karyawan.

Penerapan knowledge sharing sebagai upaya untuk meningkatkan kinerja karyawan, secara tidak langsung telah diterapkan oleh PT PLN (Persero) Kota Palopo. Adapun kegiatan knowledge sharing yang berlangsung yaitu berbagi ide-ide baru, teknik baru, pengalaman dan segala sesuatu hal yang baru yang dapat meningkatkan kinerja karyawan. Proses sharing yang dilakukan pada PT PLN (Persero) Cabang Kota Palopo yaitu berbentuk formal dan informal.

Sharing informal lebih sering dilakukan karena dapat dilakukan kapan saja dalam suatu devisi untuk memecahkan suatu permasalahan atau sekedar menyampaikan keadaan dan tanggung jawab devisi tersebut, sedangkan sharing formal berbentuk pelatihan dan pertemuan rutin, dalam pertemuan ini akan dilakukan pembahasan berbagai aspek yang ada di dalam perusahaan yang akhirnya akan menghasilkan keputusan penting bagi 
perusahaan terkait kinerja karyawan. Namun melalui wawancara yang dilakukan oleh peneliti kepada pihak devisi KSA (Keuangan, SDM dan Administrasi), ada beberapa permasalahan yang ditemui pada PT PLN (Persero) Cabang Kota Palopo yaitu proses knowledge sharing yang bekerja sama dengan pihak eksternal perusahaan terkadang tidak produktif, hal ini disebabkan karena adanya jadwal karyawan yang melakukan perjalanan dinas atau adanya urusan lain yang membuat proses knowledge sharing ini tidak berjalan dengan baik. Selain itu, bagi karyawan yang akan pensiun pengalaman kerjanya tidak dipublikasikan untuk karyawan yang masih aktif dalam bekerja, dan permasalahan tentang knowledge sharing juga ditemui antar devisi, sulit bagi karyawan antar devisi melakukan knowledge sharing, yang menjadi pemicu adalah terbatasnya pengetahuan dari karyawan antar devisi untuk mengetahui devisi tertentu. Terlebih khusus permasalahan ini biasanya terjadi pada karyawan baru, yang kurang memahami cara kerja hingga pemecahan masalah untuk suatu pekerjaan yang menjadi tanggung jawabnya.

Saefulloh (2017), menyatakan bahwa knowledge sharing memberikan pengaruh positif dan signifikan terhadap kinerja karyawan. Hal ini menunjukkan bahwa semakin baik knowledge sharing maka semakin tinggi kinerja karyawan. Hal senada ditemukan oleh Andra dan Utami (2018) bahwa terdapat pengaruh positif dan signifikan antara Knowledge Sharing terhadap kinerja Karyawan. Selain itu, Erwina dan Mira (2019) dalam penelitiannya mengemukakan bahwa terdapat pengaruh signifikan dan positif antara knowledge sharing terhadap kinerja karyawan. Hal ini menandakan bahwa penerapan knowledge sharing sangat mempengaruhi kinerja karyawan. Jika penerapan knowledge sharing yang dilakukan buruk maka kinerja dari karyawan juga akan menurun. Begitu pula sebaliknya, jika penerapan knowledge sharing baik maka kinerja dari karyawan akan mengalami peningkatan.

Berdasarkan uraian di atas, maka tujuan dari penelitian ini adalah untuk mengetahui pengaruh knowledge sharing terhadap kinerja karyawan pada PT PLN (Persero) Cabang Kota Palopo.

\section{Literature Review}

\subsection{Knowledge Sharing}

Knowledge Sharing atau berbagi pengetahuan merupakan gambaran konsep tentang interaksi berbentuk komunikasi yang terjadi antara dua orang atau lebih guna mengembangkan dan meningkatkan pengetahuan seseorang (Yusup, 2012). Sementara itu, Lumbantobing (2011) mendefinisikan knowledge sharing sebagai proses yang sistematis dalam mengirimkan, mendistribusikan, dan mendiseminasikan pengetahuan dan konteks multidimensi dari seorang atau organisasi kepada orang atau organisasi lain yang membutuhkan melalui metoda dan media yang variatif. Dimana proses ini bertujuan untuk mengoptimalkan penggunaan atau eksploitasi knowledge eksisting dan untuk mendorong penciptaan pengetahuan baru sebagai hasil pembelajaran dan kombinasi dari berbagai pengetahuan yang berbeda.

Menurut Widodo (2013), knowledge sharing merupakan perilaku yang dimiliki seseorang untuk menyebarluaskan pengetahuan dengan anggota lain dalam suatu 
organisasi sehingga dapat mencipatakan value added bagi perusahaan. Sedangkan Tobing (2011) menyatakan bahwa melalui knowledge sharing akan terjadi eksploitasi maksimal dari suatu pengetahuan. Selain mengeksploitasi pengetahuan secara maksimal, knowledge sharing juga dapat membuka kesempatan mengeksplorasi pengetahuan untuk mendapatkan atau menciptakan knowledge baru.

Menurut Tobing (2007), tacit knowledge adalah knowledge yang diam di dalam benak manusia dalam bentuk intuisi, judgement, skill, values dan belief yang sangat sulit diformalisasikan dan dibagikan dengan orang lain. Berdasarkan pengertianya, maka Tacit Knowledge dikategorikan sebagai personal knowledge atau dengan kata lain pengetahuan yang diperoleh dari individu atau perorangan. Jadi, dari beberapa pengertian menurut para ahli diatas dapat disimpulkan bahwa knowledge sharing merupakan suatu proses sistematis yang dilakukan oleh dua orang atau lebih untuk mendistribusikan pengetahuan baik melalui komunikasi satu dengan lain ataupun melalui media virtual yang ada, untuk mengembangkan, meningkatkan sehingga dapat menciptakan knowledge baru guna mendapatkan value added bagi perusahaan. Raskov dalam Memah (2017) menyatakan bahwa knowledge sharing terjadi antar individu dalam suatu komunitas, dimana individu berinteraksi dan berbagi pengetahuan dengan individu lainya melalui ruang maya atau tatap muka, Community of Practice (CoP), group, forum dan sejenisnya, sehingga unit analisis dalam knowledge sharing adalah individu.

\subsection{Kinerja Karyawan}

Kinerja dalam bahasa Inggris Job Performance atau actual performance adalah prestasi kerja atau prestasi nyata yang diraih oleh seseorang. Pengertian kinerja (prestasi kerja) yaitu hasil kerja secara kualitas dan kuantitas yang diraih oleh seorang karyawan dalam melakukan tugasnya sesuai dengan tanggungjawab yang sudah diberikan kepadanya. Kinerja merupakan perilaku nyata yang ditampilkan setiap orang sebagai prestasi kerja yang dihasilkan oleh anggota sesuai dengan perannya dalam sebuah organisasi atau dengan kata lain kinerja merupakan suatu hal yang sangat penting dalam upaya organisasi untuk mencapai tujuannya (Rivai dan Sagala, 2011:548-549). Hal senada dikemukakan oleh Gaol (2014: 273) bahwa kinerja atau performance merupakan suatu fungsi dari motivasi dan kemampuan untuk menyelesaikan tugas atau pekerjaan, di mana seseorang sepatutnya memiliki derajat kesediaan dan tingkat kemampuan tertentu. Kesediaan dan keterampilan seseorang tidaklah cukup efektif untuk mengerjakan sesuatu tanpa pemahaman yang jelas tentang apa yang akan dikerjakan dan bagaimana mengerjakannya. Kinerja merupakan hasil dari suatu proses yang mengacu dan diukur selama periode waktu tertentu berdasrkan ketentuan dan kesepakatan yang telah ditetapkan sebelumnya (Edison et al., 2016).

Dari beberapa pengertian tentang kinerja di atas maka dapat disimpulkan bahwa kinerja adalah suatu hasil kerja yang dicapai oleh karyawan secara kuantitas dan kualitas sesuai dengan tanggungjawab masing-masing karyawan untuk mencapai tujuan dari suatu perusahaan. Sementara itu, Bangun dalam Andra dan Utami (2018) mengemukakan pengukuran kinerja dapat dilakukan dengan indikator antara lain: 1) Jumlahlah pekerjaan, 2) Kualitas pekerjaan, 3) Ketepatan waktu, 4) Kehadiran, dan 5) Kemampuan kerjasama. 


\section{Metode}

\subsection{Jenis dan Sumber Data}

Penelitian ini dilakukan pada PT. PLN (PERSERO) Cabang Kota Palopo yang beralamatkan di Jl. Andi Kambo, No 70 Kota Palopo, Kelurahan Tompotika, Kecamatan Wara, Kota Palopo, Sulawesi Selatan. Data yang digunakan dalam penelitian ini adalah data primer dan data sekunder. Data primer diperoleh dari hasil observasi, kuesioner dan wawancara langsung dengan pimpinan dan karyawan PT. PLN (PERSERO) CabangKota Palopo. Data sekunder diperoleh dari Dokumentsi perusahaan dan Jurnal-jurnal serta berbagai karya ilmiah yang mendukung dalam penelitian ini.

\subsection{Populasi dan Sampel}

Populasi dalam penelitian ini yaitu seluruh karyawan PT PLN (Persero) Cabang Kota Palopo berjumlah 45 karyawan. Sampel dalam penelitian ini ditentukan dengan menggunakan sensus atau sampling total. Sensus atau sampling total adalah teknik pengambilan sampel dimana seluruh anggota populasi dijadikan sampel (Sugiyono, 2019), jadi jumlah sampel yang digunakan oleh peneliti sebanyak 45 karyawan pada PT PLN (Persero) Cabang Kota Palopo.

\subsection{Metode Analisis Data}

Peneltian ini menggunaan teknik analisis regresi sederhana dengan tujuan untuk melihat pengaruh antar variabel independen terhadap variabel dependen (Atmaja, 2009; Hamid dan Patra, 2019). Adapun persamaan regresi dapat dirumuskan sebagai berikut:

Keterangan:

$$
\widehat{Y}=a+b . X+e
$$

$$
\begin{array}{ll}
\widehat{\mathrm{Y}} & \text { : kinerja karyawan } \\
\mathrm{a} & \text { : intercept atau nilai rata-rata } \mathrm{Y} \text { prediksi jika } \mathrm{X}=0 \\
\mathrm{~b} & \text { : slope atau rata-rata perubahan pada } \mathrm{Y} \text { jika } \mathrm{X} \text { berubah } 1 \text { satuan } \\
\mathrm{X} & \text { : knowledge sharing } \\
\mathrm{e} & \text { : kesalahan prediktor }
\end{array}
$$

\section{Hasil analisis dan Pembahasan}

\subsection{Hasil Analisis}

\subsubsection{Persamaan Regresi}

\begin{tabular}{|c|c|c|c|c|c|}
\hline \multirow[b]{2}{*}{ Model } & \multicolumn{2}{|c|}{ Unstandardized Coefficients } & $\begin{array}{c}\text { Standardized } \\
\text { Coefficients }\end{array}$ & $\mathrm{T}$ & Sig. \\
\hline & $\mathrm{B}$ & Std. Error & Beta & & \\
\hline 1 (Constant) & 20.167 & 5.755 & & 3.504 & .001 \\
\hline Knowledge Sharing & .483 & .090 & .634 & 5.378 & .000 \\
\hline
\end{tabular}

Berdasarkan hasil analisis dengan menggunakan program SPSS maka diperoleh hasil regresi sebagai berikut:

\section{Tabel 1}

Hasil Analisis Regresi Linear Sederhana Coefficients $^{\mathrm{a}}$

a. Dependent Variable: Kinerja Karyawan

Sumber: Data primer diolah SPSS 23, 2020. 
Berdasarkan nilai t, diketahui nilai $t_{\text {hitung }}>t_{\text {tabel }}$ yaitu 5,378 $>2,016$ sehingga dapat disimpulkan variabel Knowledge Sharing (X) berpengaruh terhadap Kinerja Karyawan (Y). nilai koefisien korelasi sebesar 0,634 nilai tersebut termasuk pada kategori baik. Hasil pengujian hipotesis menunjukkan bahwa Knowledge Sharing berpengaruh signifikan terhadap Kinerja yang ditunjukkan oleh nilai signifikan 0,000 < 0,05 maka hal ini menunjukkan bahwa Hipotesis diterima yang menyatakan adanya pengaruh positif dan signifikan antara knowledge sharing dan kinerja karyawan. Dari hasil analisis regresi linier sederhana yang diperoleh maka dapat dibuat persamaan regresi sebagai berikut:

$\mathrm{Y}=20.167+0.483 \mathrm{X}+e$

Dari persamaan regresi, maka dapat dijelaskan sebagai berikut:

a. Nilai konstan sebesar 20,167 menunjukan bahwa variabel knowledge sharing sama dengan 0, maka kinerja pegawai sebesar 20,167

b. Kofesien regresi bernilai positif sebesar 0,483 , hal ini berarti setiap peningkatan (penambahan 1 satuan) variabel knowledge sharing maka terjadi juga peningkatan terhadap variabel kinerja sebesar 0,483.

\subsubsection{Hasil Koefisien Determinasi $\mathbf{R}^{2}$}

Hasil uji koefisien determinasi dapat dilihat hasilnya pada table dibawah ini:

\section{Tabel 2}

\section{Hasil Koefisien Determinasi $\mathbf{R}^{2}$}

Model Summary

\begin{tabular}{|l|r|r|r|r|}
\hline Model & $\mathrm{R}$ & R Square & Adjusted R Square & \multicolumn{2}{|c|}{$\begin{array}{c}\text { Std. Error of the } \\
\text { Estimate }\end{array}$} \\
\hline 1 & $.634^{\mathrm{a}}$ & .402 & .388 & 3.964 \\
\hline
\end{tabular}

a. Predictors: (Constant), Knowledge Sharing

Sumber: Data primer diolah SPSS 23, 2020

Nilai Adjusted R Square sebesar 0.402. Berdasarkan dari nilai Adjusted R Square dapat diartikan bahwa knowledge sharing mampu mempengaruhi kinerja sebesar $40.2 \%$ dan sisanya dipengaruhi oleh variabel lain yang tidak diteliti sebesar 59.8\%.

\subsection{Pembahasan}

Berdasarkan hasil analisis yang dilakukan dengan menggunakan analisis regresi linear sederhana, maka dapat disimpulkan bahwa variabel knowledge sharing berpengaruh positif dan signifikan terhadap kinerja karyawan pada PT PLN (Persero) Cabang Kota Palopo. Artinya semakin baik penerapan Knowledge Sharing maka semakin baik pula kinerja karyawan pada PT PLN (Persero) Cabang Kota Palopo, sebaliknya jika penerapan knowledge sharing tidak baik maka semakin tidak baik pula kinerja yang dihasilkan.

Hasil penelitian ini sejalan dengan penelitian yang dilakukan oleh Saefulloh (2017), yang menyatakan bahwa knowledge sharing memberikan pengaruh positif dan signifikan terhadap kinerja karyawan pada PT. UMC Cabang Bojonegoro. Hal ini menunjukkan bahwa semakin baik knowledge sharing maka semakin tinggi pula kinerja karyawan. Demikian juga dengan hasil penelitian yang juga dilakukan oleh Resti dan Hamidah 
(2018), berdasarkan analisis yang telah dilakukan, dapat dideskripsikan bahwa knowledge sharing yang dilaksanakan di PT Bank Rakyat Indonesia Kantor Cabang Malang Kawi telah berjalan baik. Sedangkan, kinerja karyawan PT. Bank Rakyat Indonesia Kantor Cabang Malang Kawi juga memiliki kinerja yang baik pula. Hal senada yang dihasilkan oleh Erwina dan Mira (2019), menunjukkan bahwa terdapat pengaruh signifikan dan positif antara knowledge sharing terhadap kinerja karyawan pada Perusahaan Air Minum (PAM) Tirta Mangkaluku Kota Palopo. Hal ini menandakan bahwa penerapan knowledge sharing sangat mempengaruhi kinerja karyawan. Jika penerapan knowledge sharing yang dilakukan buruk maka kinerja dari karyawan juga akan menurun, demikian pula sebaliknya. Sedangkan teknik analisis data yang digunakan yakni regresi linear sederhana menggunakan aplikasi statistik IBM SPSS 20.

Knowledge sharing yang dimiliki oleh PT PLN (Persero) Cabang Kota Palopo khususnya pada pengetahuan berdasarkan pengalaman perlu ditingkatkan dengan cara karyawan senior pada bidang tertentu hendaknya membagi pengalamannya dalam bekerja kepada karyawan baru dengan cara berdiskusi ataupun menyiapkan dokumentasi yang membahas tentang cara penyelesaian suatu pekerjaan agar ketepatan waktu dalam penyelesaian pekerjaan meningkat sehinggah hal ini mengakibatkan menggunaan waktu secara efektif. Sebagaimana yang dikemukakan oleh Widodo (2013), knowledge sharing merupakan perilaku yang dimiliki seseorang untuk menyebarluaskan pengetahuan dengan anggota lain dalam suatu organisasi sehinggah dapat menciptakan value added bagi perusahaan. Tujuan pelaksanaan knowledge sharing guna untuk menciptakan kesempatan yang sama bagi seluruh karyawan untuk mengakses pengetahuan dan mempelajarinya sehinggah mampu berinovasi dan menciptakan pengetahuan baru yang bermanfaat untuk penyelesaian tugas ataupun masalah dalam perusahaan oleh karena itu kinerja karyawan juga akan meningkat.

Kemudian dengan berbagi pengetahuan berdasarkan pengalaman perlu ditingkatkan agar ketepatan waktu dalam penyelesaian pekerjaan juga akan meningkat dan karyawan dapat menyelesaikan pekerjaannya secara efisien. Pengetahuan sangat penting bagi setiap karyawan dalam menjalankan tugas, karena dengan tertanamnya pengetahuan pada setiap karyawan, maka karyawan tersebut dapat menjalankan tugasnya masing-masing sesuai dengan yang diharapkan organisasi, sehinggah akan berdampak baik pada kinerja karyawan tersebut. Berdasarkan penelitian ini, maka dapat diketahui bahwa pada PT PLN (Persero) Cabang Kota Palopo menganggap sangat pentingnya pelaksanaan knowledge sharing bagi seluruh karyawan untuk menyelesaikan pekerjaan, apabila knowledge sharing tidak dilaksanakan dengan baik dalam perusahaan maka karyawan tidak bisa bekerja dengan efektif dan efisien sehinggah hal ini menyebabkan kinerja karyawan menurun. Dari hasil pembahasan di atas, maka dapat dijelaskan bahwa knowledge sharing mempunyai pengaruh positif dan signifikan terhadap kinerja karyawan pada PT PLN (Persero) Kota Palopo dalam meningkatkan kinerja karyawan karena dengan knowledge sharing karyawan dapat saling membagi pengetahuan dan pengalaman untuk penyelesaian pekerjaan yang ada dalam perusahaan. Karena, jika penerapan Knowledge Sharing semakin baik maka semakin baik pula kinerja karyawan 
yang dihasilkan, sebaliknya jika penerapan knowledge sharing kurang baik maka kinerja karyawan akan semakin buruk.

\section{Simpulan}

Berdasarkan hasil penelitian yang diperoleh, maka dapat disimpulkan bahwa knowledge sharing berpengaruh positif dan signifikan terhadap kinerja karyawan pada PT PLN (Persero) Cabang Kota Palopo. Hal ini menandakan bahwa semakin baik penerapan Knowledge Sharing maka semakin baik pula kinerja karyawan pada PT PLN (Persero) Cabang Kota Palopo, sebaliknya jika penerapan knowledge sharing kurang baik maka kinerja karyawan akan mengalami penurunan. Berdasarkan pengalaman langsung penulis pada proses penelitian ini, masih terdapat beberapa keterbatasan yang dialami oleh penulis, yang nantinya bisa dijadikan perhatian bagi penulis selanjutnya demi penyempurnaan penelitiannya. Pertama, umlah responden jumlahnya sedikit yaitu hanya 45 orang yang belum cukup representatif untuk menggambarkan keadaan sesungguhnya. Kedua, objek penelitiannya ini hanya difokuskan pada dua variable saja, jadi belum sepenuhnya memberikan gambaran tentang faktor-faktor apa saja yang mempengaruhi kinerja karyawan.

Dalam proses pengambilan data, sebagian responden masih menunjukkan persepsi yang berbeda dalam memahami setiap pernyataan/pertanyaan pada kuesioner yang diajukan oleh peneliti. Berdasarkan kesimpulan tersebut di atas, maka penulis menyarankan kepada pihak PT PLN (Persero) Cabang Kota Palopo untuk lebih meningkatkan knowledge sharing dengan cara meningkatkan seluruh aspek yang terkait dengan hal tersebut diantaranya yaitu berbagi pengetahuan berdasarkan pengalaman, dengan cara karyawan senior pada bidang tertentu hendaknya membagi pengalamannya dalam bekerja khususnya kepada karyawan baru, serta harus intens melakukan diskusi ataupun menyiapkan dokumentasi yang membahas tentang cara penyelesaian suatu pekerjaan selama dia bekerja pada perusahaan tersebut.

\section{References}

Atmaja, Lukas Setia. (2009). Statistika Untuk Bisnis dan Ekonomi. Yogyakarta: ANDI.

Andra, R Syafitri dan Utami, H Nayati. (2018). Pengaruh Knowledge Sharing Terhadap Kinerja Karyawan (Studi Pada Karyawan PT. Bank Rakyat Indonesia Cabang Malang Kawi). Jurnal Administrasi Bisnis (JAB). 61(2): 30-37

Erwina, Mira. (2019). Pengaruh Knowledge Sharing Terhadap Kinerja Karyawan Pada Perusahaan Air Minum (PAM) TIRTA Mangkaluku Kota Palopo. Jurnal Of Economic, Managemen and Accounting. 2(2): 76-77

Gaol, Jimmy L. (2014). Human Capital. Jakarta: Grasindo PT. Gramedia Widiasarana Indonesia.

Hamid, R. S., \& Patra, I. K. (2019). PENGANTAR STATISTIKA UNTUK RISET BISNIS DAN EKONOMI Konsep Dasar dan Aplikasi SPSS versi 25. Banten: $C V$. AA. RIZKY. 
Lumbantobing, Paul. (2011). Manajemen Knowledge Sharing Berbasis Komunitas. Bandung: Knowledge Management Society Indonesia.

Memah, L., Pio, R. J., \& Kaparang, S. G. (2017). Pengaruh knowledge sharing terhadap kinerja karyawan kantor perwakilan bank indonesia provinsi sulawesi utara. Jurnal Administrasi Bisnis (Jab), 5(002): 1-9.

Nawawi, Ismail. (2012). Manajemen Pengetahuan (knowledge management). Bogor: Ghalia Indonesia

Resti S A, Hamida N U. (2018). Pengaruh Knowledge Sharing Dan Motivasi Terhadap Kinerja Karyawan (Studi Pada Karyawan PT Bank Rakyat Indonesia Kantor Cabang Malang Kawi). Administrasi Bisnis Student Journal.ub.ac.id. 61(2): 31.

Rivai, H. Veitzal dan Sagala, Ella Jauvani. (2011). Manajemen Sumber Daya Manusia untuk Perusahaan. Jakarta: PT. RajaGrafindo Persada

Saefulloh S A. (2017). Pengaruh Knowledge Sharing dan Motivasi Terhadap Kinerja Karyawan Pada PT. UMC CABANG BOJONEGORO. Jurusan Manajemen Fakultas Ekonomi Universitas Negeri Surabaya. 5(2): 1-5.

Sugiyono. (2019). Metode Penelitian Kuantitatif Kualitatif Dan R\&D. Bandung (ID): Alfabeta

Tobing, Paul L. (2011). Manajemen Knowledge Sharing Berbasis Komunitas. Bandung: Graha Ilmu

Tung, K Yao. (2018). Memahami Knowledge Management. Jakarta: PT. Indeks.

Wibowo. (2017). Manajemen Kinerja. Depok: Rajawali Pers.

Widodo. (2013). Peran Knowledge Sharing Terhadap Kinerja UKM Berbasis Sikap Kewirausahaan. EKOBIS. 14(2): 17-27.

Yusup, Pawit M. (2012). Perspektif Manajemen Pengetahuan Informasi, Komunikasi, Pendidikan, dan Perpustakaan. Jakarta: Rajawali Press. 